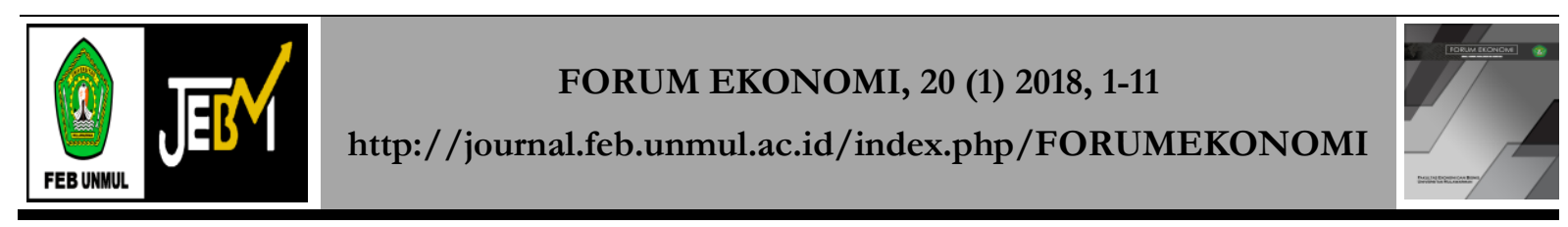

\title{
Pengaruh nilai tukar terhadap ekspor dan jumlah uang beredar di indonesia
}

\author{
Bekti Setyorani \\ Fakultas Ekonomi dan Bisnis Universitas Airlangga, Surabaya. \\ Email: bekti_rani06@yahoo.co.id
}

\begin{abstract}
Abstrak
Studi ini menganalisis pengaruh nilai tukar Rupiah dan jumlah uang bererdar terhadap Perkembangan ekspor Indonesia menggunakan data tahun 2006 kuartal I sampai tahun 2015 kuartal III dengan menggunakan Error Correction Model (ECM). Dalam kurun waktu 2006 kuartal I. Pada kurun waktu tersebut, pergerakan ekspor Indonesia secara umum mengalami tren yang positif. Penurunan jumlah ekspor terjadi pada tahun 2008 dan 2012. Pada tahun tersebut adalah kondisi dimana terjadi guncangan perekonomian global. Sementara pergerakan nilai tukar terus menunjukkan kenaikannya dari tahun per tahun. Hal ini juga berlaku pada jumlah uang beredar yang menunjukkan tren positif. Studi ini menemukan bahwa dalam jangka panjang dan jangka pendek memiliki hubungan yang signifikan antara jumlah ekspor, nilai tukar dan jumlah uang beredar.
\end{abstract}

Kata Kunci: Perkembangan ekspor; nilai tukar; jumlah uang beredar; ECM

\section{The Influence of Exchange Rate and Holding of Money on Indonesia's Exports}

\begin{abstract}
This study analyzes the influence of Rupiah exchange rate and the amount of money bererdar against Indonesia export development using data from 2006 quarter I until 2015 third quarter by using Error Correction Model (ECM). In the period of 2006 quarter I. At that time, the movement of Indonesian exports in general experienced a positive trend. The decline in the number of exports occurred in 2008 and 2012. In that year is a condition where there is a global economic shock. While exchange rate movements continue to show an increase from year to year. This also applies to the money supply that indicates a positive trend. The study finds that in the long run and short term it has a significant relationship between the amount of exports, exchange rates and the money supply.
\end{abstract}

Keywords: Export growth; exchange rate; the money supply; ECM 


\section{PENDAHULUAN}

Perdagangan luar negeri merupakan aktivitas yang dilakukan suatu negara untuk menopang perekonomiannya. Perdagangan luar negeri yang meliputi ekspor dan impor selalu terjadi antar negara di dunia sebagai upaya dalam memenuhi ketersediaan barang dan jasa penduduknya. Masing-masing negara memiliki produk unggulan dan efisien sehingga mampu diekspor ke negara lain. Ekspor menjadi penopang perekonomian suatu negara termasuk Indonesia. Ekspor memiliki peranan penting dalam perekonomian. Ekspor menjadi salah satu penyumbang cadangan devisa Indonesia. Pada tahun 2016 jumlah ekspor Indonesia mencapai 117.157.518.996 USD. Jumlah tersebut lebih besar daripada tahun sebelumnya yang hanya mencapai 150.366.291.503 USD. Produk ekspor Indonesia beraneka ragam antara lain produk manufaktur, pertanian, dan industri. Negara tujuan ekspor industri Indonesia yaitu amerika serikat, China, dan Jepang. Pertumbuhan ekonomi global pada tahun 2012 ini lebih rendah dari pada tahun sebelumnya. Penurunan ekspor ini sebagai akibat dari penurunan permintaan dari Negara tujuan utama ekspor Indonesia seperti India dan China. Komoditas yang mengalami penurunan permintaan terutama pada komoditas pertanian seperti karet dan komoditas industri seperti produk kimia. Sedangkan perlambatan ekspor yang paling utama yaitu pada sektor pertambangan dan manufaktur.

Pertumbuhan ekspor ini dipengaruhi oleh nilai tukar dan jumlah uang beredar. Nilai tukar suatu negara akan berpengaruh terhadap pertumbuhan ekspor. Nilai tukar yang semakin menguat akan berakibat pada jumlah ekspor suatu negara mengalami penurunan. Hal ini terjadi karena barangbarang di dalam negeri lebih mahal daripada barang luar negeri. Begitupun sebaliknya. Dalam penelitian Ari Mulianta (Goeltom, 1998) rupiah mendapatkan tekanan-tekanan depresiatif yang sangat besar diawali dengan krisis nilai tukar di Thailand dan menyebar ke negara ASEAN lainya. Nilai tukar rupiah secara simultan mendapatkan tekanan yang cukup berat karena besarnya kapital outflow akibat hilangnya kepercayaan investor asing terhadap prospek perekonomian Indonesia. Tekanan terhadap nilai tukar tersebut diperberat lagi dengan semakin maraknya kegiatan spekulatif buble, sehingga sejak krisis berlangsung nilai tukar sempat mengalami depresiasi hingga mencapai 75\%. Jumlah uang beredar juga berepengaruh terhadap perkembangan ekspor suatu negara. Dimana apabila jumlah uang beredar semakin meningkat maka jumlah ekpor juga semakin tinggi. Berdasarkan pemaparan di atas hubungan antara ekspor, nilai tukar dan jumlah uang beredar sangat erat kaitannya dalam mempengaruhi kondisi perekonomian suatu negara.

\section{Tinjauan Pustaka}

Departemen keuangan RI direktorat jenderal bea dan cukai, 2013. secara umum adalah kegiatan mengeluarkan/menjual barang dari dalam negeri ke luar negeri. Menurut UU kepabeanan adalah kegiatan mengeluarkan barang dari daerah pabean. Menurut Hamdani (2003:19), secara garis besar, pengertian ekspor adalah kegiatan mengeluarkan barang dari daerah pabean Indonesia ke luar negeri. (Amir, 2004) ekspor adalah mengeluarkan barang-barang dari peredaran masyarakat dan mengirimkan ke luar negeri sesuai dengan ketentuan pemerintah dan mengharapkan pembayaran dalam valuta asing.

(krugman, 2009) nilai tukar adalah harga nilai mata uang suatu negara terhadap mata uang negara lain. Nilai tukar ini dibedakan menjadi nilai tukar nominal dan nilai tukar riil. Dalam lib.ui.ac.id (Mankiw, 2007) nilai tukar nominal adalah perbandingan harga relative dari mata uang antara dua negara. Istilah "nilai tukar mata uang" antara dua negara yang diberlakukan di pasar valuta asing adalah nilai tukar mata uang nominal itu. Nilai tukar mata uang riil adalah perbandingan harga relatif dari barang yang terdapat di dua negara. Dengan kata lain, nilai tukar mata uang riil menyatakan tingkat harga dimana kita bisa memperdagangkan barang dari satu negara dengan barang negara lain.

(Bank Indonesia, 2013) Uang Beredar dapat didefinisikan dalam arti sempit (M1) dan dalam arti luas (M2). M1 meliputi uang kartal yang dipegang masyarakat dan uang giral (giro berdenominasi Rupiah), sedangkan M2 meliputi M1, uang kuasi (mencakup tabungan, simpanan berjangka dalam rupiah dan valas, serta giro dalam valuta asing), dan surat berharga yang diterbitkan oleh sistem moneter yang dimiliki sektor swasta domestik dengan sisa jangka waktu sampai dengan satu tahun.

(Ari, 2013) berdasarkan hasil analisis regresi jangka panjang ternyata nilai tukar memiliki pengaruh yang negatif dan signifikan terhadap ekspor Indonesia. Hal ini menunjukkan semakin 
kuatnya nilai tukar (apresiasi) akan menyebabkan semakin menurunnya ekspor Indonesia. Ketiga adalah dalam jangka pendek nilai tukar memiliki pengaruh yang negatif dan signifikan terhadap ekspor Indonesia. Koefisien varibel error menghasilkan tanda negatif dan signifikan yang mengandung arti bahwa konvergensi variabel ekspor untuk menuju keseimbangan terjadi jika terjadi shock dalam perekonomian.

\section{METODE}

Dalam analisis ini digunakan metode ECM atau Error Correction Model yang mengacu pada (Gujarati,2004). Metode ECM adalah metode yang digunakan untuk menguji hubungan jangka pendek dan jangka panjang dalam menyesuaikan pada kondisi keseimbangan perekonomian yang stabil. ECM yang dikembangkan oleh Engel dan Granger merupakan sarana untuk rekonsiliasi perilaku variabel ekonomi jangka pendek dengan perilaku jangka panjangnya.

Langkah-langkah ECM antara lain:

\section{Uji stasioneritas}

Data yang stasioner adalah data yang memiliki mean, varians, dan covarians konstan. Data yang tidak stasioner tidak dapat dijadikan untuk analisis lebih lanjut karena data tersebut bias dan tidak konsisten. Terdapat 3 cara dalam menguji stasioneritas data yaitu:

\section{Analisis grafis}

Analisis yang menggunakan gambar grafik dari suatu variabel untuk menguji stasioneritas dari masing-masing variabel.

\section{Corrgram}

Pada level informal, stasioner yang lemah bisa diuji dengan melakukan correlogram pada time series, yang merupakan grafik autokorelasi pada berbagai lag. Untuk time series yang stasioner, correlogram tapers off quickly, dimana untuk time series yang non-stasioner akan menghilang secara gradual.

\section{Uji unit root}

Dilakukan dengan cara uji ADF (Augmented Dicky Fuller). Dilakukan dengan melihat nilai tabel Z statistic pada masing-masing variabel. Apabila hasil regresi dari suatu model di tingkat level tidak stasioner maka dilakuakn turunan pertama pada model sampai mencapai stasioneritas pada data.

\section{Kointegrasi}

Pengujian kointegrasi dilakukan dengan menguji variabel error pada suatu model. Apabila model yang stasioner tersebut juga memiliki variabel error yang stasioner maka dapat dikatakan bahwa model tersebut terkointegrasi. Kointegrasi untuk dua atau lebih time series menunjukkan bahwa terdapat hubungan jangka panjang atau seimbang di antara mereka. Apabila model tersebut memiliki variabel error yang terkointegrasi maka model tersebut merupakan model jangka panjang.

\section{Model ECM}

Untuk memperoleh model jangka pendek dan menentukan elastisitasnya maka model ECM ini lah yang digunakan.

\section{Data}

Data yang digunakan dalam analisis ini adalah data time series . Periode yang digunakan yaitu periode tahun 2006 kuartal I sampai dengan tahun 2015 kuartal IV. Data yang digunakan dalam analisis ini adalah data sekunder. Yakni data yang diperoleh dari Badan Pusat Statistik Indonesia dan Bank Indonesia. Data yang diambil dari Badan Pusat Statistik berupa data pergerakan jumlah ekspor Indonesia berdasarkan tahun 2006 kurtal I sampai dengan tahun 2015 kurtal IV. Sedangkan data yang diambil dari Bank Indonesia yaitu data nilai tukar transaksi (nilai tukar tengah) berdasarkan perbandingan mata uang rupiah dengan USD pada tahun 2006 kurtal I sampai dengan tahun 2015 kuartal IV. selain itu dari Bank Indonesia juga diperoleh data jumlah uang beredar (M2) pada periode tahun 2006 kuartal I sampai dengan tahun 2015 kuartal IV. dalam hasil data kuantitatif data diolah dengan menggunakan STATA 13. 


\section{HASIL DAN PEMBAHASAN}

\section{Perkembangan Ekspor di Indonesia}

Nilai ekspor Indonesia dari kurun waktu 2006-2015 secara umum menunjukkan tren yang positif. Hal ini dapat dilihat pada tahun 2006 kuartal I hingga tahun 2008 kuartal II mengalami kenaikan. Demikian juga pada tahun 2009 kuartal I sampai dengan tahun 2011 kuartal IV. Nilai ekspor ini mencapai jumlah tertinggi pada tahun 2011 kuartal II sebesar USD 18.386.000.000. Namun pada tahun 2012-2015 nilai ekspor mengalami penurunan hingga mencapai USD 13.808.000.000. Pada tahun 2012 terjadi pelemahan perekonomian global yang berdampak pada turunnya ekspor Indonesia.

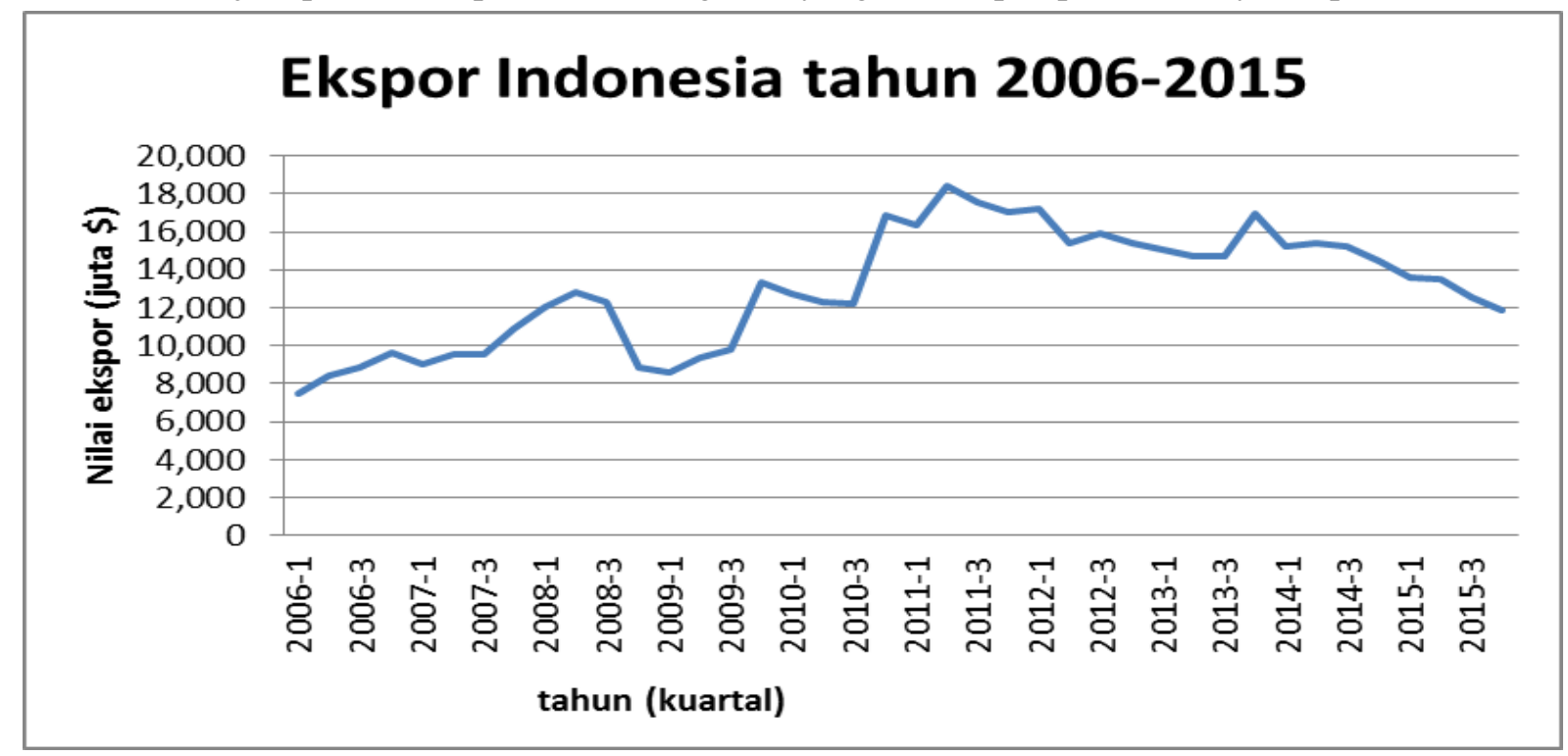

Gambar 1. Nilai Ekspor Indonesia tahun 2006-2015

Sumber: Badan Pusat Statistik (2015), diolah

Permasalahan perekonomian dunia di Negara kawasan Eropa dan Amerika Serikat mengalami guncangan ekonomi sehingga hal ini berdampak pada Negara berkembang seperti Indonesia. Pertumbuhan ekonomi global pada tahun 2012 ini lebih rendah daripada tahun sebelumnya. Penurunan ekspor ini sebagai akibat dari penurunan permintaan dari Negara tujuan utama ekspor Indonesia seperti India dan China. Komoditas yang mengalami penurunan permintaan terutama pada komoditas pertanian seperti karet dan komoditas industry seperti produk kimia. Sedangkan perlambatan ekspor yang paling utama yaitu pada sektor pertambangan dan manufaktur. Penurunan ini dipicu oleh turunnya harga-harga komoditi terutama migas di pasar internasional pada tahun tersebut. (Bank Indonesia, 2013).

\section{Perkembangan Nilai Tukar di Indonesia}

Nilai tukar menjadi faktor utama dalam lalu lintas perdagangan dunia. Smaghi (2008) ketidakseimbangan global berasal dari asimetri dalam sistem nilai tukar, di mana negara-negara maju, setelah runtuhnya sistem Bretton Woods 1971, pada umumnya telah menerapkan sistem nilai tukar mengambang murni. Sementara itu, banyak negara-negara emerging markets yang pada praktiknya masih menjalankan sistem mengambang terkendali. Dengan sistem ini, banyak negara emerging yang menjadikan ekspor sebagai sumber pertumbuhan. Sehingga apabila terjadi gejolak pada nilai tukar maka akan berpengaruh pada nilai ekspor. 


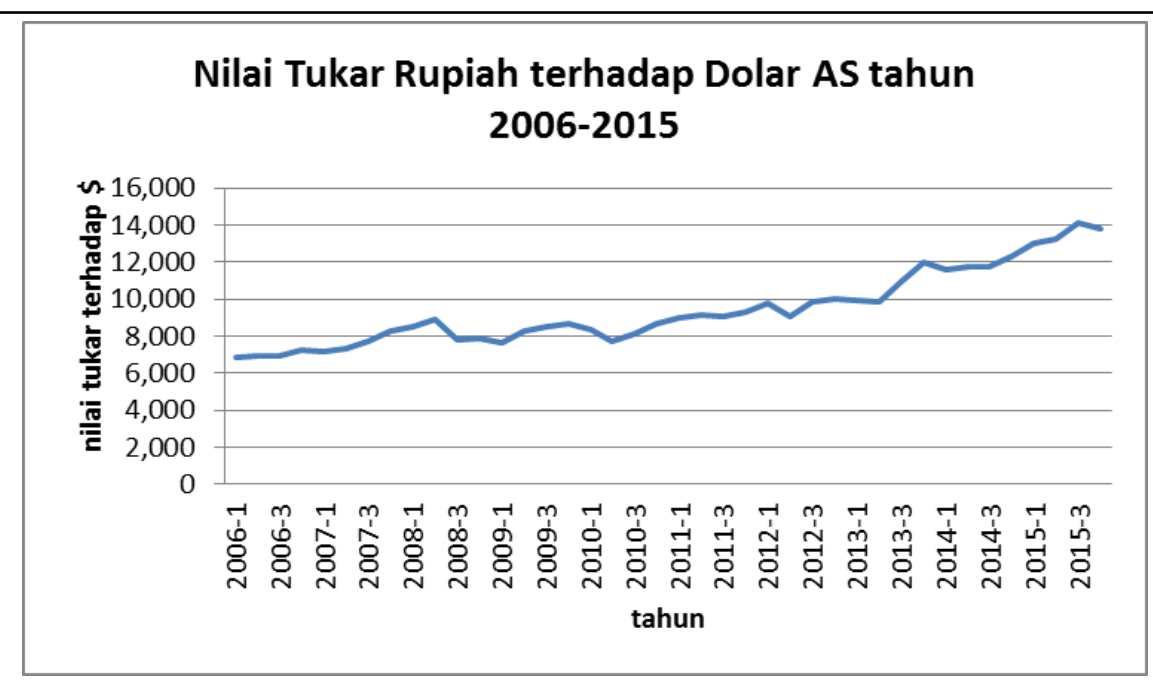

Gambar 2. Nilai Tukar Rupiah terhadap Dolar AS tahun 2006-2015

Sumber: Bank Indonesia (2015)

Pada gambar 2 nilai tukar rupiah terhadap dolar secara umum menunjukkan kenaikan. Hal ini berarti nilai tukar terdepresiasi atau melemah. Nilai tukar yang melemah mengakibatkan surplus pada neraca perdagangan. Hal ini dikarenakan harga barang di dalam negeri menjadi lebih murah daripada harga barang di luar negeri. Oleh karena itu, depresiasi menyebabkan peningkatan ekspor suatu negara. Namun yang terjadi di Indonesia pada kurun waktu tersebut peningkatan ekspor hanya terjadi pada tahun 2006 kuartal I hingga 2008 kuartal I. Pada tahun selanjutnya terjadi penurunan ekspor sebagai dampak dari krisis global.

\section{Pergerakan Nilai Tukar dan Jumlah Uang Beredar}

Krugman (2009) Pergerakan nilai tukar akan merubah pergerakan jumlah uang yang beredar. Dalam kondisi nilai tukar yang terapresiasi maka jumlah uang beredar akan berkurang dan dalam kondisi depresiasi maka jumlah uang beredar akan bertambah. Kondisi ini digambarkan dalam keseimbangan simultan di pasar uang dan pasar nilai tukar di Amerika Serikat. Dimana pada gambar 4 disamping dijelaskan kurva yang menghubungkan antara pasar uang dan pasar nilai tukar. Sehingga jumlah uang beredar erat kaitannya dengan nilai tukar yang berdampak pada perubahan nilai ekspor di pasar barang. Apabila jumlah uang beredar ditambah maka akan menyebabkan kurva nilai tukar bergeser ke atas yang berarti terjadi deperesiasi dan sebaliknya.

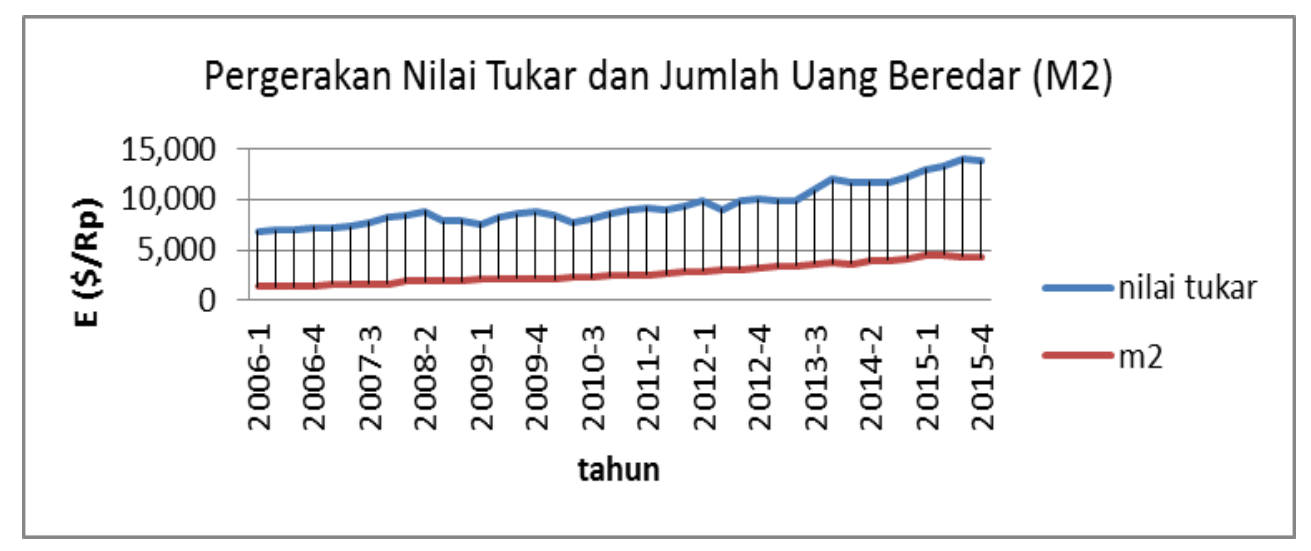

Gambar 3. Pergerakan Nilai Tukar dan Jumlah Uang Beredar (M2) tahun 2006-2015

Sumber: Bank Indonesia (2015) 
Pada gambar 3 diatas nilai tukar Indonesia tahun 2006-2015 sebanding dengan jumlah uang beredar. Nilai tukar terus mengalami kenaikan yang berarti terjadi depresiasi pada kurun waktu tersebut seiring dengan penambahan jumlah uang beredar.

\section{Hasil Analisa Kuantitatif} berikut:

Model ekonometrika dari variabel ekspor, nilai tukar, dan jumlah uang beredar adalah sebagai

Keterangan:

$$
X t=\beta 0+\beta 1 E t+\beta 2 M 2 t+\mu t
$$

$\mathrm{X}=$ nilai ekspor (juta dollar AS)

$\mathrm{E} \quad=$ nilai tukar $(\$ / \mathrm{Rp})$

M2 = jumlah uang beredar dalam arti luas (triliun rupiah)

Metode dari penelitian ini menggunakan metode ECM seperti yang dijelaskan di awal. Data yang digunakan dalam penelitian adalah data time series sehingga rawan dengan autokorelasi dan stasioneritas. Di dalam penelitian ini tidak akan membahas mengenai masalah autokorelasi namun membahas mengenai stasioneritas data. Data yang tidak stasioner artinya data tersebut memiliki mean, varian, dan covarians yang tidak konstan. Sehingga untuk melihat stasioneritas data digunakanlah metode ECM. Tahap pertama dalam metode ECM yaitu uji stasioneritas. Gujarati (2004) Uji stasioneritas dapat dilakukan dengan 3 cara yaitu:

1) Analisis Grafik

- Stasioner : grafik yang terbentuk bergerak disekitar rata

- Tidak stasioner : grafik yang terbentuk bergerak ke arah positif atau negatif (memiliki tren)
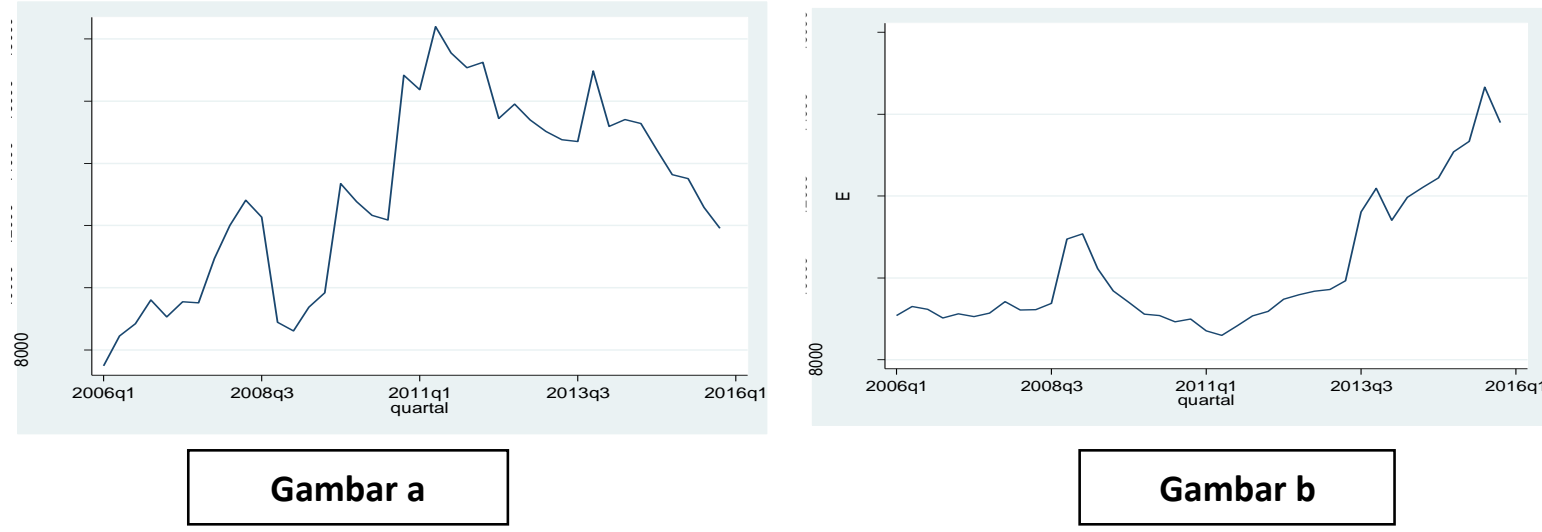

Gambar a

Gambar b

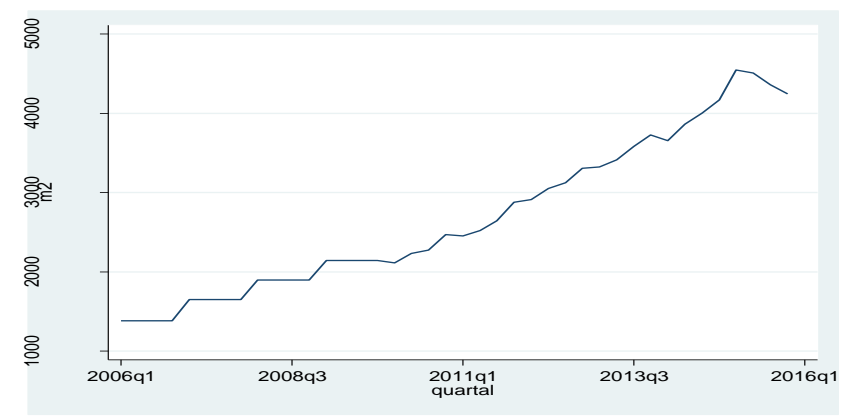

Gambar c

Gambar a : grafik nilai ekspor bergerak ke arah yang positif atau memiliki tren naik sehingga variabel nilai ekspor tidak stasioner.

Gambar b : grafik nilai tukar bergerak ke arah yang positif atau memiliki tren sehingga variabel nilai tukar tidak stasioner.

Gambar c : grafik jumlah uang beredar bergerak kea rah positif atau memiliki tren naik sehingga 
variabel jumlah uang beredar tidak stasioner.

2) Correlogram

- Stasioner : garis tidak banyak yang keluar dari sumbu vertical autokorelasi

- Tidak stasioner : garis banyak yang keluar dari sumbu vertical autokorelasi

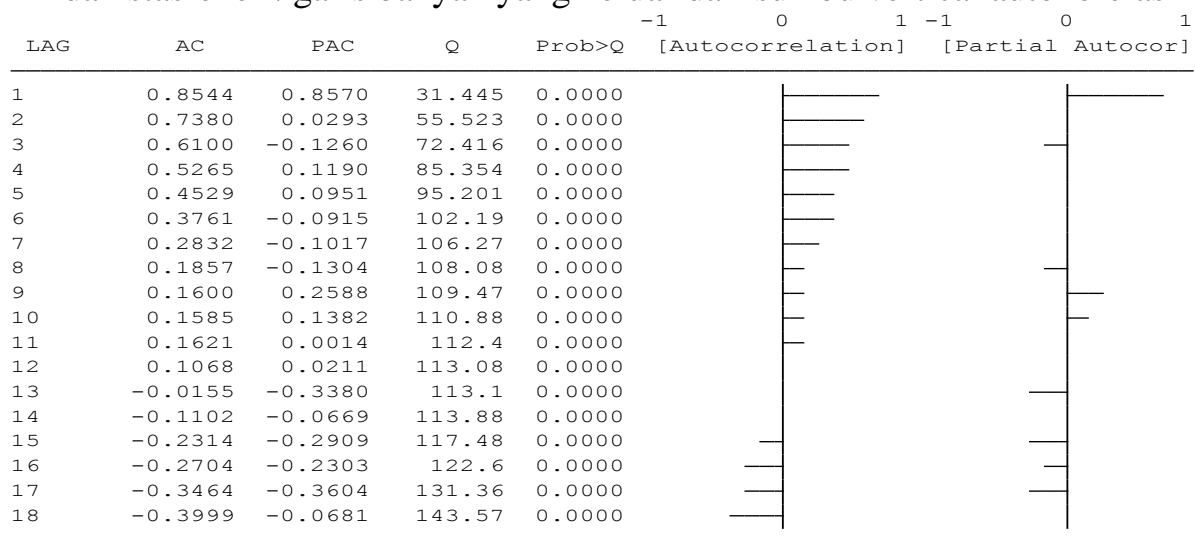

Grafik nilai ekspor $=$ tidak stasioner

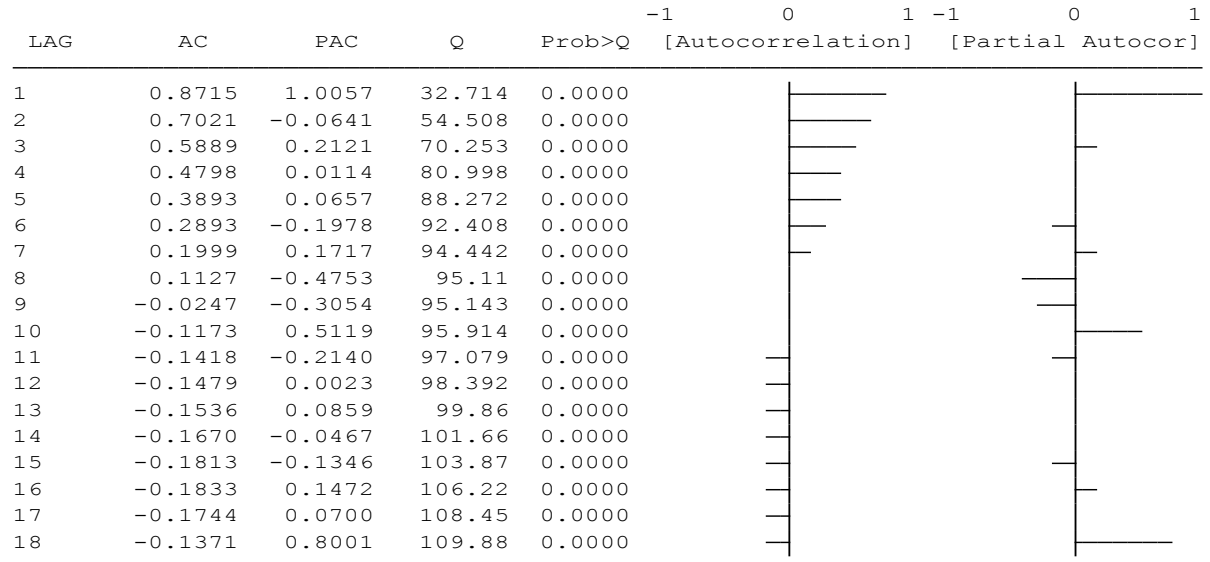

Grafik Nilai tukar $=$ tidak stasioner

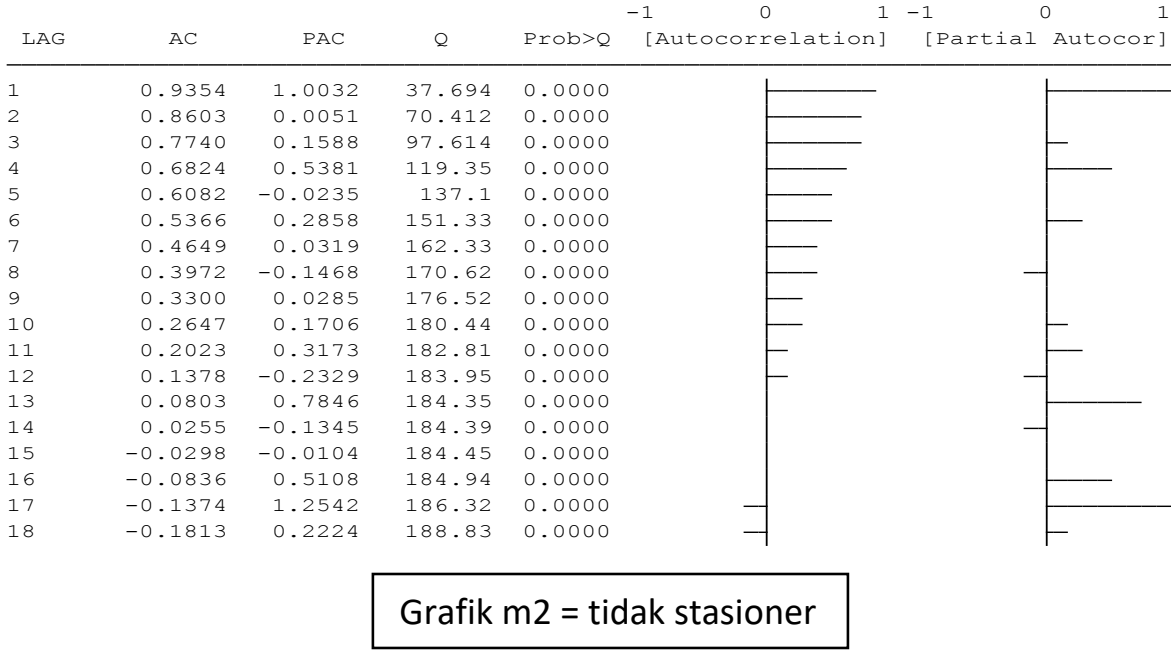

3) Uji Unit root 


\begin{tabular}{|c|c|c|c|c|c|c|c|c|}
\hline \multirow[b]{2}{*}{ Variabel } & \multicolumn{4}{|c|}{ ADF tingkat level } & \multicolumn{4}{|c|}{ ADF tingkat first different } \\
\hline & $\begin{array}{l}\text { nilai Z } \\
\text { statistik }\end{array}$ & CV 5\% & $\begin{array}{c}\text { p- } \\
\text { value }\end{array}$ & signifikansi & $\begin{array}{l}\text { nilai Z } \\
\text { statistik }\end{array}$ & CV 5\% & p-value & signifikansi \\
\hline \multirow[t]{2}{*}{ Ekspor } & & & 0.2689 & tidak & & & 0.0000 & \\
\hline & -2.041 & -2.961 & & stasioner & -6.432 & -2.964 & & stasioner \\
\hline E / nilai & & & 0.5386 & tidak & & & 0.0000 & \\
\hline tukar & 0.098 & -1.687 & & stasioner & -5.402 & -2.964 & & stasioner \\
\hline \multirow[t]{2}{*}{ M2 } & & & 0.5634 & tidak & & & 0.0000 & \\
\hline & 0.161 & -1.687 & & stasioner & -5.838 & -2.964 & & stasioner \\
\hline
\end{tabular}

a. Hipotesis

HO : tidak stasioner

H1 : stasioner

Kaidah pengambilan keputusan

Jika Zstatistik > CV maka H0 ditolak = stasioner

Jika Zstatistik $<$ CV maka H0 tidak ditolak = tidak stasioner

Hasil unit root menunjukkan bahwa pada tingkat level atau Ordinary Least Square (OLS) ketiga variabel tersebut tidak stasioner yang artinya mean, varians, dan covariansnya tidak konstan. Hal ini ditunjukkan pada nilai $\mathrm{Z}$ statistik yang kurang dari critical value. Jika tetap dipaksakan menggunakan hasil tersebut maka tidak memenuhi uji asumsi normalitas karena hasilnya akan bias dan tidak dapat dipercaya. Pada nilai kritis atau critical value 5\% semua variabel berada pada Ho diterima yang berarti tidak stasioner. Oleh sebab itu, agar variabel tersebut stasioner maka harus di-first difference kan sehingga menjadi stasioner. Pada tingkat first difference nilai $\mathrm{Z}$ statistik lebih dari critical value hal ini berarti berada pada Ho ditolak yang berarti data stasioner.

Pengujian Kointegrasi

Uji kointegrasi diperlukan untuk mengetahui ada tidaknya hubungan dalam jangka panjang pada variabel di dalam model. Pengujian yang dilakukan pada variabel error. Jika variabel error yang diuji stasioner maka data tersebut terkointegrasi atau terjadi keseimbangan dalam jangka panjang.

\section{Hasil output pengujian kointegrasi}

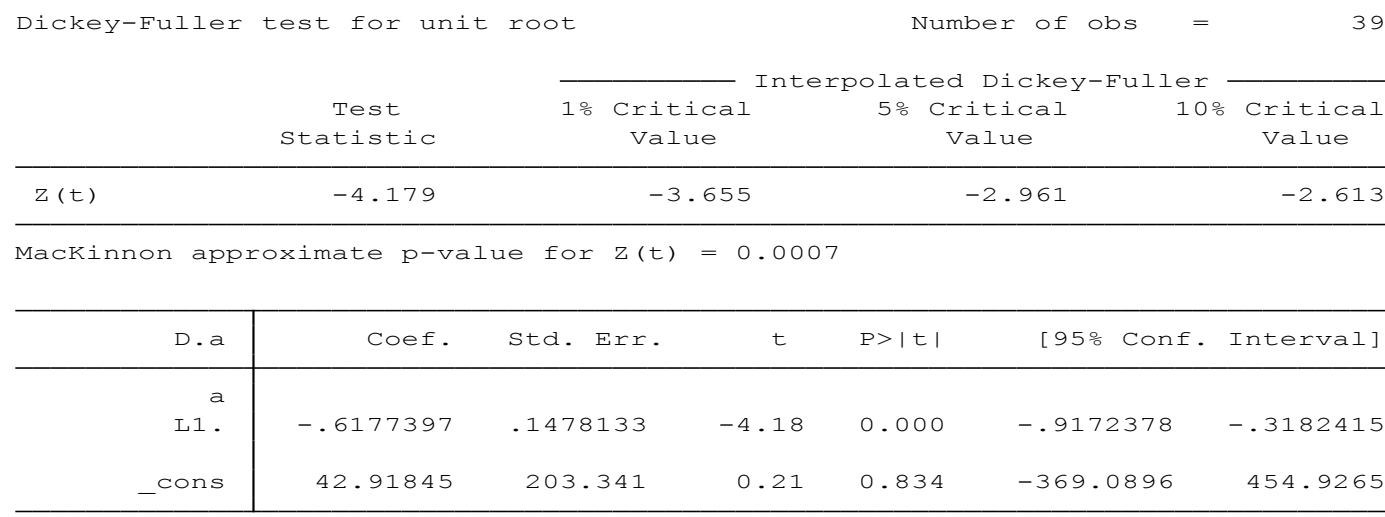

Uji hipotesis

H0 : variabel tidak terkointegrasi

H1 : variabel terkointegrasi

Kaidah keputusan

Jika Zstatistik $>\mathrm{CV}$ maka H0 ditolak = terkointegrasi

Jika Zstatistik < CV maka H0 tidak ditolak = tidak terkointegrasi 
Dari output di atas dapat dijelaskan bahwa nilai Zstatistik lebih besar daripada critical value yang artinya $\mathrm{H} 0$ ditolak sehingga variabel tersebut terkointegrasi atau terjadi keseimbangan dalam jangka panjang. Selain itu P value juga menunjukkan nilai 0.0007 dimana nilai tersebut kurang dari 0.005 yang berarti signifikan. Oleh karena itu, dapat disimpulkan bahwa ketiga variabel (ekspor, nilai tukar, dan jumlah uang beredar) memiliki keseimbangan dalam jangka panjang.

\section{Error Correction Model (ECM)}

Jika variabel error pada model tersebut tersebut terkointegrasi maka artinya variabel tersebut terjadi keseimbangan dalam jangka panjang. Oleh karena itu metode ECM ini dapat digunakan untuk mengetahui seberapa cepat variabel ekspor, nilai tukar, dan jumlah uang beredar menuju pada keseimbangannya dalam jangka panjang.

\section{Keseimbangan dalam jangka panjang}

Model keseimbangan jangka panjang

$\mathrm{Xt}^{*}=22316.03-2.121 \mathrm{E}_{\mathrm{t}}{ }^{*}+4.595 \mathrm{M} \mathbf{t}_{\mathrm{t}}{ }^{*}$

. reg ekspor e m2

\begin{tabular}{|c|c|c|c|c|c|}
\hline Source & SS & $d f$ & MS & Number of obs & 40 \\
\hline Model & 287273395 & 2 & 143636698 & Prob $>F$ & 0.0000 \\
\hline Residual & 74220992 & 37 & 2005972.76 & R-squared & 0.794 \\
\hline Total & 361494387 & 39 & 9269086.85 & Root MSE & 1416. \\
\hline
\end{tabular}

\begin{tabular}{r|rrrrrr}
\hline ekspor & Coef. & Std. Err. & $t$ & $P>|t|$ & [95\% Conf. Interval] \\
\hline $\mathrm{e} 2$ & -2.121562 & .2358965 & -8.99 & 0.000 & -2.599534 & -1.643591 \\
$\mathrm{~m} 2$ & 4.595206 & .3851103 & 11.93 & 0.000 & 3.814898 & 5.375513 \\
-cons & 22316.03 & 1710.875 & 13.04 & 0.000 & 18849.47 & 25782.59 \\
\hline
\end{tabular}

Interpretasi:

Variabel nilai tukar memiliki dampak yang signifikan terhadap ekspor Indonesia. Hubungan antara nilai tukar dengan ekspor adalah negative. Hal ini sesuai dengan teori bahwa ketika nilai tukar naik (apresiasi) maka jumlah ekspor akan mengalami penurunan. Pada hasil output diatas kenaikan nilai tukar sebesar \$1 akan menurunkan jumlah ekspor sebanyak 2,1 juta dollar.

Variabel jumlah uang beredar juga memiliki dampak yang signifikan terhadap jumlah ekspor Indonesia atau memiliki hubungan yang sangat erat. Pada hasil output di atas hubungan antara jumlah uang beredar dan ekspor adalah positif atau berbanding lurus. Hal ini sesuai teori bahwa ketika jumlah uang beredar di suatu Negara terlalu banyak artinya jumlah ekspor sedang mengalami kenaikan. Hasil di atas menunjukkan nilai 4,595 yang artinya ketika jumlah uang beredar naik satu triliun rupiah maka jumlah ekspor akan naik sebesar 4,595 juta rupiah

R-square menunjukkan jumlah 0,79 artinya variabel nilai tukar dan jumlah uang beredar mampu menjelaskan faktor yang mempengaruhi jumlah ekspor sebesar $79 \%$. Sisanya sebesar $21 \%$ dipengaruhi oleh faktor lain di luar model.

\section{Keseimbangan dalam jangka pendek}

Model jangka pendek

$$
\Delta \mathrm{Xt}^{*}=\mathbf{7 2 . 4 1 8 - 1 . 0 9 1} \Delta \mathrm{E}_{\mathrm{t}}{ }^{*+2.471} \Delta \mathrm{M} 2 \mathrm{t}^{*}-0.510 \varepsilon_{\mathrm{t}-1}
$$

\section{Keterangan:}

$$
\begin{array}{ll}
\mathrm{X} & =\text { Jumlah ekpor } \\
\mathrm{E} & =\text { Nilai tukar }
\end{array}
$$




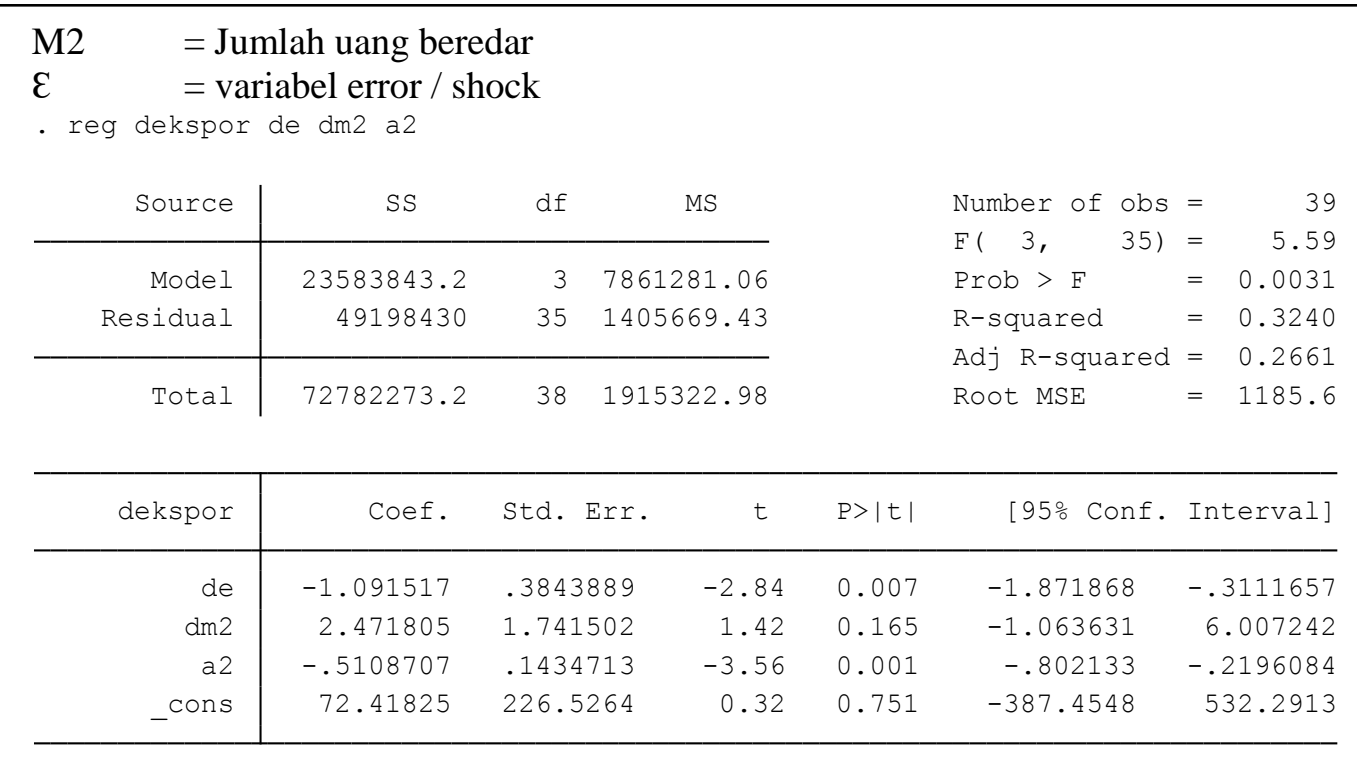

Dari hasil output di atas dapat diinterpretasikan bahwa kecepatan penyesuaian variabel ekspor, nilai tukar dan jumlah uang beredar selama setengah tahun. Atau dalam hal ini apabila ekspor naik dan diikuti penurunan pada nilai mata uang maka kebijakan yang dilakukan adalah menaikan nilai tukar dan menurunkan jumlah uang beredar agar perekonomian kembali di kondisi keseimbangan dan tidak terjadi depresiasi secara terus menerus. Koefisien dari a2 sebesar 0,5 berarti proses penyesuaian kebijakan untuk menuju keseimbangannya adalah paling pendek setengah tahun. Nilai a2 menunjukkan hasil negatif hal ini sesuai dengan syarat variabel error yang harus bernilai negatif (kebijakan yang dilakukan harus berbanding terbalik dengan kondisi awal) dengan tujuan menuju keseimbangan perekonomian dalam jangka panjang. Oleh karena itu, apabila pemerintah melakukan kebijakan menaikan atau menurunkan nilai tukar dan jumlah uang beredar maka akan membutuhkan proses untuk menuju keseimbangan jumlah ekspor paling sedikit setengah tahun.

\section{SIMPULAN}

Berdasarkan hasil penelitian di atas dapat ditarik tiga kesimpulan yang paling penting. Pertama, berdasarkan data nilai ekspor Indonesia dari kurun waktu 2006-2015 secara umum menunjukkan tren yang positif. Namun pada tahun 2012-2015 nilai ekspor mengalami penurunan pada tahun 2012 terjadi pelemahan perekonomian global yang berdampak pada turunnya ekspor Indonesia. Penurunan ekspor ini sebagai akibat dari penurunan permintaan dari Negara tujuan utama ekspor Indonesia seperti India dan China. Perlambatan ekspor yang paling utama yaitu pada sektor pertambangan dan manufaktur. Sementara nilai tukar rupiah terhadap dolar secara umum menunjukkan kenaikan. Hal ini berarti pada tahun 2006-2015 nilai tukar terdepresiasi atau semakin melemah. Nilai tukar yang terus melemah ini juga diikuti dengan pertambahan jumlah uang beredar yang semakin meningkat pada kurun waktu tersebut

Kedua, pada periode jangka panjang variabel nilai tukar dan jumlah uang beredar memiliki pengaruh yang signifikan terhadap jumlah ekspor dengan tingkat signifikansi 0,000 . Hubungan antara nilai tukar dengan ekspor adalah negative. Pada hasil output diatas kenaikan nilai tukar sebesar $\$ 1$ akan menurunkan jumlah ekspor sebanyak 2,1 juta dollar. Sementara itu, hubungan antara jumlah uang beredar dan ekspor adalah positif atau berbanding lurus. Ketika jumlah uang beredar naik satu triliun rupiah maka jumlah ekspor akan naik sebesar 4,595 juta rupiah. Asumsi dari ketiga variabel tersebut pada kondisi ceteris paribus. R-square menunjukkan jumlah 0,79 artinya variabel nilai tukar dan jumlah uang beredar mampu menjelaskan faktor yang mempengaruhi jumlah ekspor sebesar $79 \%$. Sisanya sebesar $21 \%$ dipengaruhi oleh faktor lain di luar model. Disamping itu, nilai dari variabel error menunjukkan kointegrasi atau memiliki hubungan dalam jangka panjang. 
Ketiga, pada periode jangka pendek koefisien dari a2 atau variabel error sebesar 0,5 berarti proses penyesuaian kebijakan untuk menuju keseimbangannya adalah paling cepat setengah tahun. Artinya apabila pemerintah melakukan kebijakan menaikan atau menurunkan nilai tukar dan jumlah uang beredar maka akan membutuhkan proses untuk menuju keseimbangan jumlah ekspor paling sedikit setengah tahun. Nilai negatif menunjukkan bahwa apabila nilai ekspor mengalami kenaikan terus menerus maka harus diturunkan agar berada pada perekonomian yang kembali stabil atau seimbang

\section{DAFTAR PUSTAKA}

Badan Pusat Statistik. 2017. http://www.bps.go.id. Diakses pada 5 Januari 2017.

Bank Indonesia.2013. http: //www.bi.co.id diakses pada 5 januari 2017.

Departemen keuangan RI direktorat jenderal bea dan cukai. 2013. http ://www.beacukai.co.id. diakses pada 8 januari 2017.

Direktur Jenderal Bea dan Cukai, 1996, Undang-undang No.10 Tahun 1995 Tentang Kepabeanan, Direktorat Jenderal Bea dan Cukai, Jakarta.

Hamdani. 2003. Seluk Beluk Perdagangan Ekspor Impor. Jakarta : Yayasan Bina Usaha Niaga Indonesia,

Mankiw, N. Gregory, 2007. Makroekonomi. Edisi Keenam. Jakarta: Erlangga.

M.S, Amir. 2004. Strategi memasuki pasar Ekspor. Jakarta: Penerbit PPM.

Mulianta, Ari Ginting. 2013. Pengaruh Nilai Tukar Terhadap Ekspor Indonesia. Jakarta : Pusat Pengkajian, Pengolahan Data dan Informasi (P3DI), Bidang Ekonomi dan Kebijakan Publik.

Krugman, Paul.R, 2009. International Economics Theory \& Policy. Eighth edition. University of California Barkeley : Maurice Obstfeld.

Univeristas Indonesia. http:lib.ui.ac.id/file?file=digital/127014-6556-Analisis\%20pengaruhLiteratur.pdf diakses pada 8 januari 2017. 